\title{
Genetically similar VHSV isolates are differentially virulent in olive flounder Paralichthys olivaceus
}

\author{
Mi Young Cho ${ }^{1, *}$, Unn Hwa Lee ${ }^{2, *}$, Chang Hoon Moon ${ }^{3}$, Jong Deuk Bang ${ }^{1}$, \\ Bo Young Jee ${ }^{1}$, Seung Ju Cha ${ }^{1}$, Jin Woo Kim ${ }^{1}$, Myoung Ae Park ${ }^{4}$, Jeong Wan Do ${ }^{4, * *}$, \\ Jeong Woo Park ${ }^{2, * *}$
}

\begin{abstract}
${ }^{1}$ Aquatic Life Disease Control Division, National Fisheries Research and Development Institute, Busan 619-705, South Korea
${ }^{2}$ Department of Biological Sciences, University of Ulsan, Ulsan 680-749, South Korea

${ }^{3}$ Biomedical Research Center, Ulsan University Hospital, University of Ulsan College of Medicine, Ulsan 682-060, South Korea

${ }^{4}$ Division of Pathology, National Fisheries Research and Development Institute, Busan 619-705, South Korea
\end{abstract}

\begin{abstract}
Two viral hemorrhagic septicemia virus (VHSV) isolates, VHSV-KR-CJA and VHSVKR-YGH, were isolated from viral hemorrhagic septicemia disease outbreaks in flounder farms in South Korea. The VHSV-KR-CJA isolate was isolated from a flounder farm with high mortality $(80 \%)$, while the VHSV-KR-YGH isolate was isolated from a flounder farm with low mortality $(15 \%)$, suggesting that these isolates differ in virulence. The virulence of these isolates was evaluated in juvenile flounder via intraperitoneal injection. Consistent with their virulence in the field, mortality data revealed that the VHSV-KR-CJA isolate was highly pathogenic (cumulative mortality of $80 \%$ ), while the VHSV-KR-YGH isolate was less pathogenic in flounder (cumulative mortality of $20 \%$ ). To characterize the genotypes of these viruses, the full open reading frames (ORFs) encoding nucleoprotein $\mathrm{N}$, phosphoprotein $\mathrm{P}$, matrix protein $\mathrm{M}$, glycoprotein $\mathrm{G}$, nonstructural viral protein NV, and polymerase $\mathrm{L}$ of these viruses were sequenced and analyzed. Sequence analysis revealed that both isolates are genetically very similar (identical amino acid sequences for $\mathrm{P}, \mathrm{M}, \mathrm{NV}$, and $\mathrm{L}$ and $>99.7$ and $99.8 \%$ amino acid sequence identity for $\mathrm{N}$ and $\mathrm{G}$, respectively). Phylogenetic analysis indicated that both of these viruses belong to the Genotype IVa group, suggesting that they originated from a common ancestral virus. The low pathogenicity VHSV strain may potentially evolve to become a more pathogenic strain through only a few nucleotide substitutions. Further functional analyses of mutations in VHSV genes are necessary to identify factors that determine VHSV pathogenicity in flounder.
\end{abstract}

KEY WORDS: Viral hemorrhagic septicemia virus $\cdot$ VHSV $\cdot$ Virulence $\cdot$ Flounder

\section{INTRODUCTION}

Viral hemorrhagic septicemia virus (VHSV), the causative agent of viral hemorrhagic septicemia (VHS), is an enveloped negative-strand RNA virus in the genus Novirhabdovirus of the family Rhabdoviridae (Walker et al. 2000). The VHSV genome consists of approximately 11200 nucleotides and contains 6 genes that encode a non-structural protein (NV) and 5 structural proteins: nucleoprotein $(\mathrm{N})$, phosphoprotein $(\mathrm{P})$, matrix protein $(\mathrm{M})$, glyco- protein (G) and RNA polymerase (L) arranged in the order 3'-N-P-M-G-NV-L-5' (Schütze et al. 1999). VHSV was first isolated from rainbow trout in Europe (Jensen 1965), where it causes serious economic problems in rainbow trout farming (Wolf 1988, Smail 1999). Later, VHSV was isolated from several marine fish species in northern hemisphere waters near Japan, Europe, and North America (Mortensen et al. 1999, Takano et al. 2000, Hedrick et al. 2003), indicating the widespread occurrence of this virus in the marine environment. 
Phylogenetic analyses of the $\mathrm{N}$ - and G-encoding genes of VHSV have identified 4 main genotypes (I to IV), with several subgroups within Genotypes I (minimum Ia to Ie) and IV (IVa and IVb) (Snow et al. 1999, Einer-Jensen et al. 2004, Lumsden et al. 2007). These genotypes reflect a largely geographic rather than a species-specific distribution. Genotype I includes a wide range of viruses originating from freshwater rainbow trout farms in continental Europe (Thiéry et al. 2002, Einer-Jensen et al. 2004) and a large number of isolates originating from marine species in the Baltic Sea, Skagerrak, Kattegat, and English Channel (Dixon et al. 1997, Einer-Jensen et al. 2004, Snow et al. 2004). Genotype II includes a limited number of VHSV isolates recovered from the Baltic Sea (Snow et al. 2004). Genotype III includes isolates from the North Sea (Einer-Jensen et al. 2004, Snow et al. 2004), North Atlantic (López-Vázquez et al. 2006), and from seawater-reared rainbow trout in western Norway (Dale et al. 2009). Genotype IV consists of viruses from the Pacific coast and Atlantic coast of North America as well as isolates from the Great Lakes region of North America and from Asia (Nishizawa et al. 2002, Kim et al. 2003, Elsayed et al. 2006, Gagné et al. 2007, Lumsden et al. 2007).

VHSV isolates from wild marine fish are serologically (Winton et al. 1989, Einer-Jensen et al. 1995, Benmansour et al. 1997) and genetically (EinerJensen et al. 2004, Snow et al. 2004, Campbell et al. 2009) similar to those from fish farms, but marine isolates typically produce little or no mortality in rainbow trout fry following waterborne challenge (Dixon et al. 1997, Campbell et al. 2009). The close genetic similarity of high and low pathogenicity VHSV isolates indicates that only small differences in the virus genome may be involved in the determination of VHSV virulence in rainbow trout (Betts \& Stone 2000, Campbell et al. 2009). It has been experimentally shown that the growth of a non-pathogenic marine isolate is severely inhibited at the initial stage of virus infection in immersion-challenged rainbow trout (Campbell et al. 2011). However, factors influencing the growth of genetically similar VHSV isolates have not yet been determined.

VHSV was first isolated in Asian countries in 1996 from cultured flounder Paralichthys olivaceus, which is an important fish species in aquaculture (Takano et al. 2000). Since then, VHSV infections have been reported in many flounder farms in Japan (Isshiki et al. 2001, Takano et al. 2001) and Korea (Kim et al. 2003, 2009). All VHSV isolates from cultured flounder in Asia thus far identified belong to the Genotype IVa clade.
In this study, we isolated 2 VHSV isolates, VHSVKR-CJA and VHSV-KR-YGH, from viral hemorrhagic septicemia disease outbreaks in flounder farms in Korea, determined their genotypes, and tested their pathogenicity in flounder. Field data and experimental mortality testing revealed that the VHSV-KR-CJA isolate is highly pathogenic but that the VHSV-KR-YGH is much less pathogenic in cultured flounder. Sequence analysis of genes encoding the N, P, M, G, NV, and L proteins revealed a high amino acid similarity between the 2 isolates, and both isolates were classified into the Genotype IVa group of VHSV viruses. This paper is the first to report VHSV isolates that are genetically similar but differentially virulent in flounder.

\section{MATERIALS AND METHODS}

\section{Cell line}

The epithelioma papillosum cyprinid (EPC) cell line was grown in Eagle's minimal essential medium (MEM) supplemented with $10 \%$ fetal bovine serum (GIBCO-BRL) at 15 to $19^{\circ} \mathrm{C}$.

\section{Viruses}

In April 2010, VHS outbreaks occurred at olive flounder farms from 2 separate areas in South Korea: one at Wando on the Korean mainland and the other at Jeju Island (Fig. 1). Flounder fingerlings from Wando and Jeju Island experienced 15 and $80 \%$ mortalities, respectively. VHSV isolates were

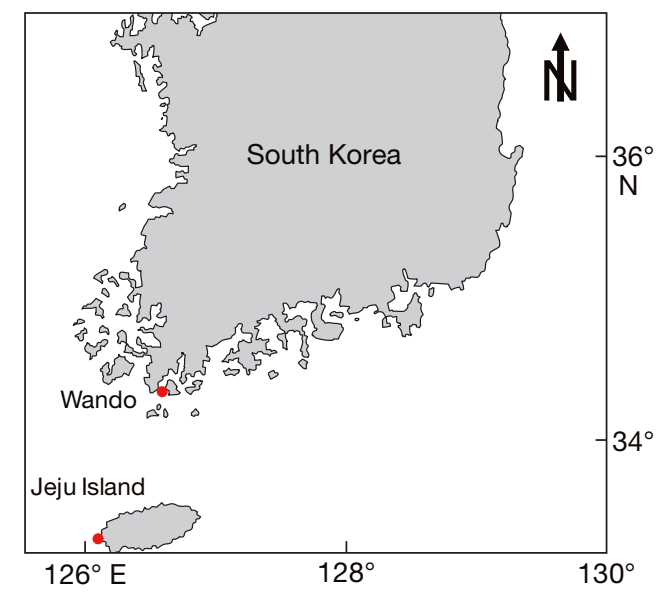

Fig. 1. Location of fish farms where epizootics occurred and from which the viral hemorrhagic septicemia viruses (VHSVs) were isolated 
obtained from tissues collected from the visceral organs of moribund fish. Briefly, pooled visceral organs from 5 fish were homogenized in 9 volumes of MEM supplemented with $10 \%$ fetal bovine serum containing penicillin and streptomycin. Homogenates were centrifuged $\left(15 \mathrm{~min}, 4000 \times \mathrm{g}, 4^{\circ} \mathrm{C}\right)$ and filtered aseptically through a $0.45 \mu \mathrm{m}$ pore diameter membrane filter. The filtrate was inoculated into EPC cells in 24-well dishes at final dilution ratios of $1: 100$ and 1:1000. Inoculated cultures were incubated at $16^{\circ} \mathrm{C}$ and observed regularly under a microscope for the occurrence of cytopathic effects (CPE). When CPE were evident, the cell culture medium was collected. Once a full cytopathic response had been observed, the virus was stored at $-80^{\circ} \mathrm{C}$ and virus stocks were quantified by a standard plaque assay (Batts \& Winton 1989). The host species, location, and year of isolation of the VHSV isolates used in this study are provided in Table 1.

\section{Pathogenicity experiments in flounder}

To test the pathogenicity of the VHSV isolates, olive flounder were experimentally infected. Flounder fingerlings weighing $10.9 \pm 0.3 \mathrm{~g}$ (mean $\pm \mathrm{SE}$ ) were purchased from a commercial fish farm without a history of VHS for the prior $3 \mathrm{yr}$, and 20 to 40 fish were stocked in each tank and acclimated for $1 \mathrm{wk}$. VHSV isolates used in the pathogenicity test had a low passage number (less than 7 passages) and were propagated and titrated on EPC cells. Fish in duplicate tanks were intraperitoneally (i.p.) infected with VHSV isolates or control media in an inoculum volume of $50 \mu \mathrm{l}$, representing a dose of $1 \times 10^{5}$ plaqueforming units (PFU) per fish. Fish were anesthetized by bathing them in benzocaine solution, and then i.p. injected with a new needle and syringe for each isolate and transferred to tanks. Tanks were monitored twice daily for fish showing signs of ill health. Cumulative mortalities at the end of the trial within and between different groups in each experiment were compared by chi-square analysis. A p-value less than 0.05 was considered statistically significant.

Table 1. Sources of hemorrhagic septicemia viruses (VHSVs) isolated from cultured flounder in South Korea

\begin{tabular}{|lccc|}
\hline Isolate & Fish weight (g) & Date (yr/mo) & Region \\
\hline VHSV-KR-CJA & $5-6$ & $2010 / 04$ & Jeju \\
VHSV-KR-YGH & $5-6$ & $2010 / 04$ & Wando \\
\hline
\end{tabular}

\section{Histological examination}

Tissue samples from the kidney, spleen, liver, and gill were fixed with Bouin's solution. Fixed tissues were dehydrated in alcohol (70 to $100 \%$ ) and embedded in paraffin. Tissue sections ( $4 \mu \mathrm{m}$ thick) were stained with hematoxylin and eosin (H\&E) solution and then examined under a light microscope (Carl Zeiss, Axiolab).

\section{RNA extraction, cDNA synthesis, and PCR amplification}

Total RNA was extracted from pooled tissues of moribund fish or virus-infected cells using Trizol according to the manufacturer's protocol (Invitrogen). cDNA was synthesized from total RNA using reverse transcriptase (Beams). Partial genes of infectious hematopoietic necrosis virus (IHNV), VHSV, nodavirus, hirame rhabdovirus (HIRRV), iridovirus, and marine birnavirus, and full length open reading frames (ORFs) of the genes encoding the $\mathrm{G}, \mathrm{N}, \mathrm{P}$, and nonvirion protein of the VHSV isolates were amplified by PCR using PCR primers (Table 2). The PCR products were cloned into the pGEM-T Easy vector (Promega), and sequencing was performed by Solent, Korea, on an automatic DNA sequencer (ABI3730XL, Applied Biosystems) with forward and reverse primers and overlapping primers designed from the sequencing results.

\section{Sequence analysis}

Nucleotide BLAST analysis was used to identify related reference viruses, and reference sequences were obtained from GenBank. The nucleotide sequences and the deduced amino acid sequences were aligned using CLUSTAL W (Thompson et al. 1994) and the phylogenetic tree was constructed using TreeView (Page 1996). The phylogenetic relationships among species were determined using the neighbor-joining (NJ) method (Saitou \& Nei 1987) and the reliability of the NJ tree was inferred using the Felsenstein (1985) bootstrap method with 1000 replicates.

\section{Nucleotide sequence accession numbers}

The nucleotide sequence data reported in this paper were deposited in GenBank (GenBank acces- 
sion numbers: VHSV-KR-CJA G, JQ651393; VHSVKR-CJA N, JQ651390; VHSV-KR-CJA P, JQ651391; VHSV-KR-CJA M, JQ651392; VHSV-KR-CJA NV, JQ651394; VHSV-KR-CJA L, JQ821352; VHSV-KRYGH G, JQ651388; VHSV-KR-YGH N, JQ651385; VHSV-KR-YGH P, JQ651386; VHSV-KR-YGH M, JQ651387, VHSV-KR-YGH NV, JQ651389, VHSVKR-YGH L, JQ821351).

\section{RESULTS AND DISCUSSION}

In 2010, mortalities occurred among the fingerlings of flounders cultured at 2 fish farms located in Wando on the Korean mainland and on Jeju Island, 2 geographically distant locations (Fig. 1, Table 1). The net losses of fingerlings at the affected farms were $15 \%$ in Wando and $80 \%$ on Jeju Island. The diseased fish showed typical VHS lesions: exophthalmia, small hemorrhages in the eye orbits and skin, dark body coloration, an expanded abdomen due to ascites, pale gill coloration, and internally, a congested liver, splenomegaly, swollen kidney, and occasional hemorrhage in the lateral musculature. Parasites and bacteria were not consistently recovered from the organs of the diseased fish.

Previously, several fish viruses such as VHSV (Kim et al. 2003, 2009), IHNV (Park et al. 1993, Kim et al. 2007), HIRRV (Kim et al. 2005), marine birnavirus (Sohn et al. 1995), beta nodavirus (Cha et al. 2007), and iridovirus (Do et al. 2005) have been isolated from flounders cultured in Korea. Thus, at first, we screened the moribund fish for these viruses by RT-PCR using PCR primers specific for genes from these fish viruses. Only VHSV genes were amplified from flounders from both farms (data not shown). These results suggested that the causative agent could be VHSV. Next, we inoculated EPC cells with tissue homogenates from moribund fish obtained from the 2 farms and detected CPE in these cells. The virus isolates were identified as VHSV by RT-PCR and we named the VHSV isolates from Wando and Jeju Island VHSV-KR-YGH and VHSV-KR-CJA, respectively.

Table 2. PCR primers used for gene amplification. VHSV: viral hemorrhagic septicemia virus; MABV: marine birnavirus; FLIV: flounder iridovirus; IHNV: infectious hematopoietic necrosis virus; HIRRV: hirame rhabdovirus

\begin{tabular}{|c|c|c|}
\hline Virus & Primer & Sequence \\
\hline \multirow[t]{20}{*}{ VHSV } & \multirow[t]{2}{*}{ VHSV-G1 } & 5'-ATG GCA CAT TTG TGT ACA CAA CAA GC-3' \\
\hline & & 5'-TCA GAC CGT CTA CTT CTG GAG A-3' \\
\hline & \multirow[t]{2}{*}{ VHSV-G2 } & 5'-ATT GGA TCA AGA CCG ACC TG-3' \\
\hline & & 5'-TCA CAG TCA CCT CGC ATG AT-3' \\
\hline & \multirow[t]{2}{*}{ VHSV-N } & 5'-TGA ACA AAA GAA CTC AGT CGA AA-3' \\
\hline & & 5'-AAT CGT GCC GTT TTT TTC TAT CTA-3' \\
\hline & \multirow[t]{2}{*}{ VHSV-NV } & 5'-TAC GGG ATT CCG ATG CAG CAG TTC TCC AGA A-3' \\
\hline & & 5'-TGT TGA GTG TAG GAY TAC AAA CAA C-3' \\
\hline & \multirow[t]{2}{*}{ VHSV-P } & 5'-GRC AAA CAC YGA AAT CAC ACA-3' \\
\hline & & 5'-GAT GCR TTG TGT TGT CCC TAC T-3' \\
\hline & \multirow[t]{2}{*}{ VHSV-M } & 5'-AAC TCC CAA AGA GAG ACG CTC CA-3' \\
\hline & & 5'-TTT TTC TAT CTA ATG GGA GYG TG-3' \\
\hline & \multirow[t]{2}{*}{ VHSV-L1 } & 5'-TGA CCC TAC AGG GGG TAA TAC-3' \\
\hline & & 5'-GAG ATC TGA GAA GGT CAT GGT-3' \\
\hline & \multirow[t]{2}{*}{ VHSV-L2 } & 5'-CAG GTT CTC CGA GAG AGC ATC-3' \\
\hline & & 5'-GAT GTT TCG AAT TTG GTA GGC-3' \\
\hline & \multirow[t]{2}{*}{ VHSV-L3 } & 5'-ATC ACA TAG CCA CCA TGG ATC-3' \\
\hline & & 5'-TGG CAA TTC CCT CGA TGT GGA-3' \\
\hline & \multirow[t]{2}{*}{ VHSV-L4 } & 5'-ATC CAA GTG GCA AGG CTC ACC-3' \\
\hline & & 5'-CAG GGG AAG TCA CGT GGT CAT-3' \\
\hline \multirow[t]{2}{*}{ MABV } & \multirow[t]{2}{*}{ MABV-VP2 } & 5'-GCC GAC ATT GTG AAC TCA AC-3' \\
\hline & & 5'-TTG AGG TTG GGA GGT CAC TT-3 \\
\hline \multirow[t]{2}{*}{ Nodavirus } & \multirow[t]{2}{*}{ NODA-VP2 } & 5'-GAC GTC CAT CTC ACG GGT AT-3' \\
\hline & & 5'-GCG AGG GAA TCG TTG TAG AG-3' \\
\hline \multirow[t]{2}{*}{ FLIV } & \multirow[t]{2}{*}{ FLIV-MCP } & 5'-GAT CAG GTG CCA CTC AAA GCG TG-3' \\
\hline & & 5'-GGT ACC GTC CAC CTG TCA TCA TCA C-3' \\
\hline \multirow[t]{2}{*}{ IHNV } & \multirow[t]{2}{*}{ IHNV-G } & 5'-CG AGG TAT CCA AGG ACA GGA-3' \\
\hline & & 5'-GAT GGG GTA CGG ATT TGA TG-3' \\
\hline \multirow[t]{2}{*}{ HIRRV } & \multirow[t]{2}{*}{ HIRRV-G } & 5'-CAA GGT TTA CCG AAC CA-3' \\
\hline & & 5'-GGT GGT GTC CAT AGC TCG TT-3' \\
\hline
\end{tabular}


We evaluated the pathogenicity of the isolates in flounder fingerlings by i.p. inoculation. Consistent with their field history, the VHSV-KR-YGH and VHSV-KR-CJA isolates produced a cumulative mortality of $20 \%$ (15 to $25 \%$ ) and $80 \%$ (77 to $83 \%$ ), respectively (Fig. 2). Infected fish showed signs typical of VHS, and VHSV genes were isolated from dead fish by RT-PCR. Negative control fish had a cumulative mortality of $5 \%(5 \%$ and $5 \%$ in both tanks). However, VHSV genes were not detected in the dead fish from the negative control group. Collectively, our results indicated that while KR-CJA is highly pathogenic in flounder, KR-YGH is much less pathogenic in these fish.

VHSV isolates have been classified into 4 genotypes (I to IV) and several subgroups (Ia to Ie in Genotype I; IVa and IVb in Genotype IV) based on the sequences of the genes encoding G and N (Snow et al. 1999, Einer-Jensen et al. 2004, Lumsden et al. 2007). To determine the genetic characteristics of our 2 VHSV isolates, we amplified the full-length ORFs

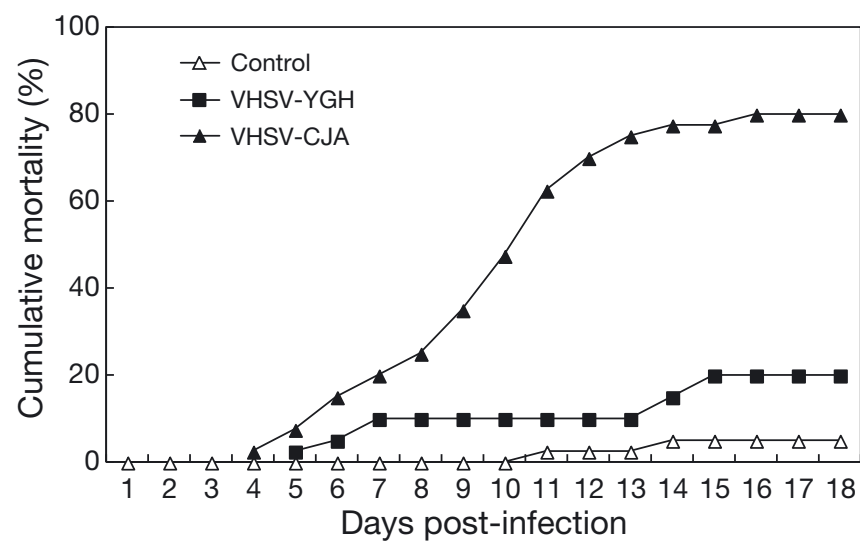

Fig. 2. Paralichthys olivaceus. Mean cumulative mortality $(\%)$ in Japanese flounder $(10.5 \pm 1.0 \mathrm{~g})$ exposed to viral hemorrhagic septicemia virus isolates VHSV-KR-CJA or VHSVKR-YGH via intraperitoneal injection at a dose of $1 \times 10^{5} \mathrm{PFU}$ per fish. Media was administered to a negative control group, and tanks were duplicated in all cases. Fish length was $10.9 \pm 0.3 \mathrm{~cm}$ of $\mathrm{G}$ and $\mathrm{N}$ by PCR. In addition, we amplified the fulllength ORFs of the genes encoding $\mathrm{M}, \mathrm{P}, \mathrm{NV}$, and $\mathrm{L}$. We cloned the PCR products into the pGEMt vector and sequenced the inserts. Each nucleotide position in the genes was determined at least twice from each DNA strand. The $P, M$, and NV sequences of the 2 isolates were identical (Table 3). The N, G, and L ORFs are 1215, 1524, and 5955 bp in length and code for proteins of 404, 507, and 1984 amino acids, respectively. One nucleotide and 1 amino acid in the $\mathrm{N}$ and $\mathrm{G}$ genes and proteins, respectively, were different between the 2 isolates, whereas there were 2 silent nucleotide changes in the $\mathrm{L}$ gene between the 2 isolates (Table 3 ). The percentage nucleotide sequence identity among the 3 genes (N, G, and L) of the 2 isolates was over $99.9 \%$, and the predicted amino acid sequence similarity of the $\mathrm{N}, \mathrm{G}$, and $\mathrm{L}$ genes were 99.7, 99.8, and $100 \%$, respectively. These results suggest that the 2 isolates originated from the same progenitor viruses. To characterize the genetic origin of the 2 VHSV isolates, we compared the full amino acid sequences of the G protein of the $2 \mathrm{VHSV}$ isolates to those of 31 other VHSV isolates available in GenBank (Table 4).

Consistent with previous reports (Snow et al. 1999, Einer-Jensen et al. 2004, Lumsden et al. 2007), 4 VHSV groups corresponding to 4 genotypes (I to IV) were evident in the phylogenetic tree. Both VHSVKR-CJA and VHSV-KR-YGH isolates clustered within Genotype IV. VHSV Genotype IV is subdivided into IVa and IVb. VHSV isolates from the Pacific coast of North America, Great Lakes and Asia are classified into IVa and those from the Atlantic coast of North America into IVb (Elsayed et al. 2006, Gagné et al. 2007). Both VHSV-KR-CJA and VHSV-YGH isolates shared the highest similarity with VHSV isolates from flounder in Japan (JP99Obama25, JF00Ehi1 and KRRV9822) and Korea (JF-KR) and belong to subgroup IVa (Fig. 3A). A phylogenetic tree produced with the $\mathrm{N}$ gene sequences also grouped these isolates into subgroup IVa (data not shown).

Table 3. Comparison of nucleotide (nt) and amino acid (aa) sequences of gene encoding N, P, M, G, NV, and L between the viral hemorrhagic septicemia virus isolates VHSV-KR-CJA and VHSV-KR-YGH

\begin{tabular}{|c|c|c|c|c|c|c|}
\hline \multirow[t]{2}{*}{ Gene } & \multicolumn{3}{|c|}{ Nucleotide sequence } & \multirow{2}{*}{ Size (aa) } & \multirow{2}{*}{$\begin{array}{l}\text {-Amino acid sequence } \\
\text { Number of substitutions }\end{array}$} & \multirow[b]{2}{*}{ Identity $(\%)$} \\
\hline & Size (nt) & Number of substitutions & Identity (\%) & & & \\
\hline $\mathrm{N}$ & 1215 & 1 & 99.9 & 404 & 1 & 99.7 \\
\hline $\mathrm{P}$ & 669 & 0 & 100 & 222 & 0 & 100 \\
\hline M & 606 & 0 & 100 & 201 & 0 & 100 \\
\hline $\mathrm{G}$ & 1524 & 1 & 99.9 & 507 & 1 & 99.8 \\
\hline NV & 369 & 0 & 100 & 122 & 0 & 100 \\
\hline $\mathrm{L}$ & 5955 & 2 & 99.9 & 1984 & 0 & 100 \\
\hline
\end{tabular}


Table 4. Viral isolates and GenBank accession numbers for the G sequences used to generate Fig. 3

\begin{tabular}{|c|c|c|c|c|c|}
\hline Virus isolate & Year of isolation & Origin & Host species & Genotype & Accession number \\
\hline VHSV-KR-CJA & 2010 & Korea & Olive flounder & IVa & JQ651393 \\
\hline VHSV-KR-YGH & 2010 & Korea & Olive flounder & IVa & JQ651388 \\
\hline JF-KR & 2001 & Korea & Olive flounder & IVa & AY167587 \\
\hline OFGn & 2010 & Korea & Olive flounder & IVa & HQ687076 \\
\hline PhGn & 2010 & Korea & Pacific herring & IVa & HQ687075 \\
\hline PcGn & 2010 & Korea & Pacific cod & IVa & HQ687074 \\
\hline RtGw5 & 2010 & Korea & Rainbow trout & IVa & HQ687073 \\
\hline FJeju05 & 2005 & Korea & Olive flounder & IVa & FJ811902 \\
\hline FYeosu05 & 2005 & Korea & Olive flounder & IVa & FJ811901 \\
\hline FWando05 & 2005 & Korea & Olive flounder & IVa & FJ811900 \\
\hline Inje07 & 2007 & Korea & Manchurian trout & IVa & FJ561738 \\
\hline YBS05 & 2005 & Korea & Yellowback seabream & IVa & GU265815 \\
\hline LH03 & 2003 & Korea & Largehead hairtail & IVa & GU265814 \\
\hline KF05 & 2005 & Korea & Buffer fish & IVa & GU265813 \\
\hline BF05-1 & 2005 & Korea & Buffer fish & IVa & GU265809 \\
\hline DK-F1 & 1962 & Denmark & Rainbow trout & I & AF345857 \\
\hline DK-Hededam & 1972 & Denmark & Rainbow trout & I & Z93412 \\
\hline Dsa67-01 & 2001 & Germany & Rainbow trout & I & EU708781.1 \\
\hline Dau686-97 & 1997 & Germany & Rainbow trout & I & EU708748.1 \\
\hline Dau1556-98 & 1998 & Germany & Rainbow trout & I & EU708752.1 \\
\hline $1455-07$ & 2007 & Slovenia & Rainbow trout & I & GQ292534.1 \\
\hline Hededam-Denmark-70 & 1970 & Denmark & Brown trout & I & U28798.1 \\
\hline FR-07-71 & 1971 & France & Rainbow trout & Ia & AF345859 \\
\hline DK-200070-4 & 2000 & Denmark & Rainbow trout & Ia & AY546612 \\
\hline Fi13 & 1983 & Germany & Rainbow trout & Ia & Y18263.1 \\
\hline $96-43$ & 1996 & English Channel & Herring & $\mathrm{Ib}$ & AF143862 \\
\hline SE-SVA-1033 & 2000 & Kattegat & Rainbow trout & $\mathrm{Ib}$ & FJ460591 \\
\hline Cod-Ulcus & 1979 & Denmark & Atlantic cod & $\mathrm{Ib}$ & Z93414.2 \\
\hline JP96KRRV9601 & 1996 & Japan & Rainbow trout & $\mathrm{Ib}$ & DQ401190.1 \\
\hline DK4p37 & 1997 & North Sea & Blue whiting & $\mathrm{Ib}$ & FJ460590.1 \\
\hline NO-F-2009 & 2009 & Norway & Herring & $\mathrm{Ib}$ & HM632035.1 \\
\hline DK-1p12 & 1996 & Baltic Sea & Herring & $\mathrm{Ib}$ & AY546574.1 \\
\hline DK-5151 & 1988 & Denmark & Rainbow trout & Ic & AF345859.1 \\
\hline NO-A16368G & 1968 & Norway & Rainbow trout & Id & AY546621.1 \\
\hline FiA01.00 & 2000 & Finland & Rainbow trout & Id & AY546614.1 \\
\hline $14-58$ & 1999 & France & Rainbow trout & Id & AF143863.1 \\
\hline FiA03-04 & 2004 & Finland & Rainbow trout & Id & AM086382.1 \\
\hline FI-ka66 & 2000 & Bothnia & Rainbow trout & Id & AY546614.1 \\
\hline $23-75$ & 1975 & France & Brown trout & Id & FN665788.1 \\
\hline FiP03-01 & 2001 & Finland & Rainbow trout & Id & AM086364.1 \\
\hline GE-1.2 & 1981 & Georgia & Rainbow trout & Ie & AY546619.1 \\
\hline DK-1p52 & 1996 & Baltic Sea & Sprat & II & AY546576.1 \\
\hline DK-1p53 & 1996 & Baltic Sea & Herring & II & AY546577.1 \\
\hline CK-1p55 & 1996 & Baltic Sea & Sprat & II & AY546578.1 \\
\hline DK-4p168 & 1997 & Skagerrak & Herring & III & AY546582.1 \\
\hline IR-F13.02.97 & 1997 & Ireland & Turbot & III & AY546620.1 \\
\hline FR-L59X & 1987 & France & Eel & III & AY546618.1 \\
\hline JF00Ehi1 & 2000 & Japan & Olive flounder & IVa & AB490792.1 \\
\hline JP99Obama25 & 1999 & Japan & Olive flounder & IVa & DQ401191 \\
\hline KRRV9822 & 1998 & Japan & Olive flounder & IVa & AB179621.1 \\
\hline ME03 & 2003 & USA & Muskellunge & IVa & DQ401192.1 \\
\hline Makah & 1988 & USA & Coho salmon & IVa & $\mathrm{U} 28747.1$ \\
\hline WA91Clearwater & 1991 & USA & Coho salmon & IVa & DQ401189.1 \\
\hline BC93-372 & 1993 & Canada & Pacific herring & IVa & DQ401186.1 \\
\hline BC99-001 & 1999 & Canada & Pacific sardine & IVa & DQ401195.1 \\
\hline U13653 & 2005 & Canada & Drum & IVb & HQ453209.1 \\
\hline CA-NB00-01 & 2000 & Canada & Mummichog & $\mathrm{IVb}$ & EF079896.2 \\
\hline CA-NB02-01 & 2002 & Canada & Striped bass & $\mathrm{IVb}$ & EF079897.2 \\
\hline CA-NS04-01 & 2004 & Canada & Brown trout & $\mathrm{IVb}$ & EF079899.2 \\
\hline
\end{tabular}




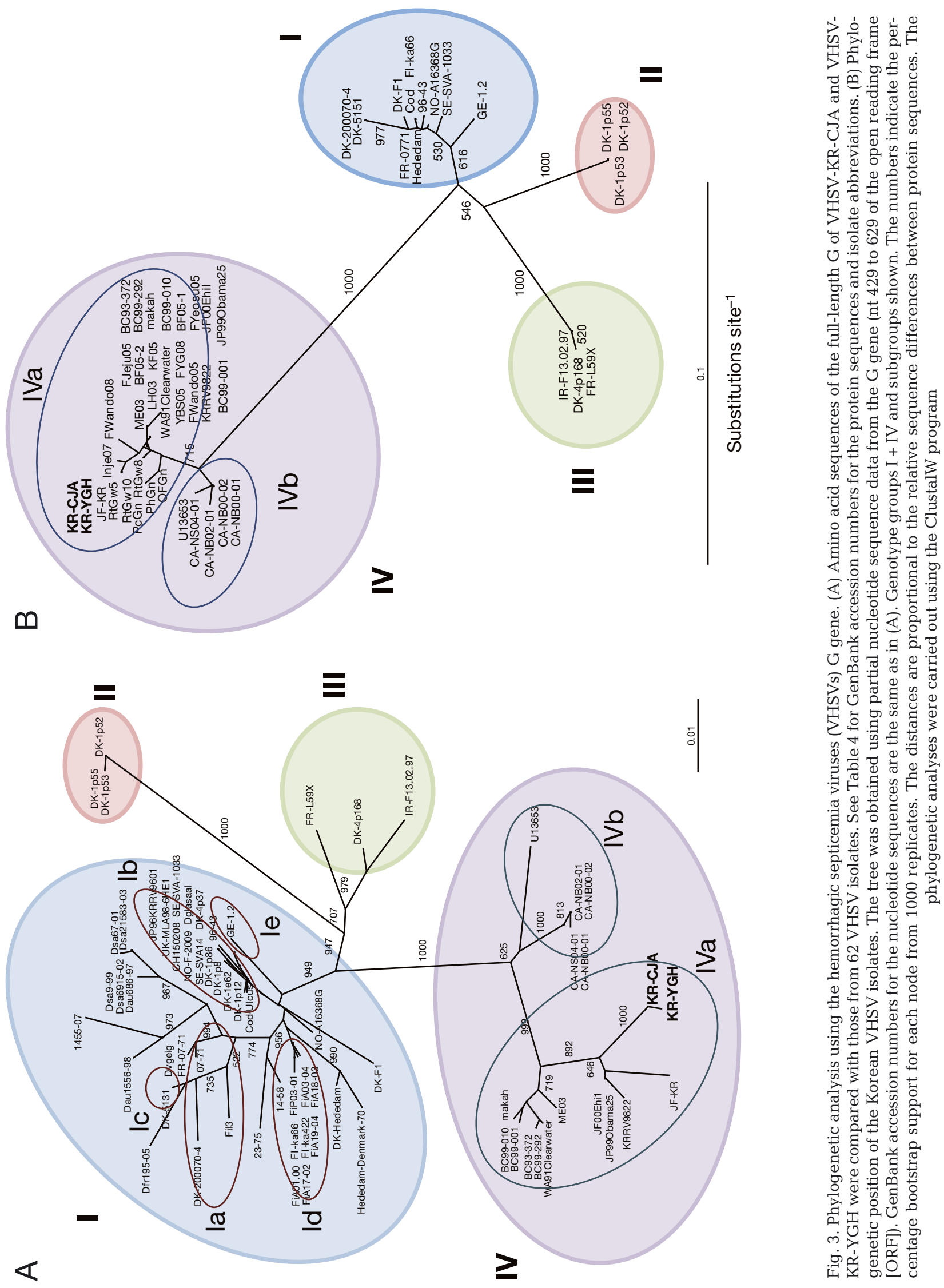


Since the first isolation of VHSV from cultured flounder in 2001 (Kim et al. 2003), VHSV has been detected not only in cultured flounder, but also in wild marine fishes in Korea (Kim et al. 2003, Kim \& Park 2004, Lee et al. 2007), indicating the widespread occurrence of VHSV in the marine environment. To determine the genetic origin of the VHSVKR-CJA and VHSV-KR-YGH isolates, we compared their G sequences with those of VHSVs isolated from both cultured flounder and other wild marine fishes in Korea (Table 4). Except for 1 Korean isolate, JF$\mathrm{KR}$, for which the full-length ORF of $\mathrm{G}$ was determined (Kim et al. 2003), only partial G sequences of other Korean isolates are available in GenBank and, thus, only 201 nucleotides of the G gene sequence (nucleotides 429 to 629 of the ORF) of the Korean VHSV isolates were used in the analysis. As shown in Fig. 3B, the VHSV isolates from marine fishes in Korea were found to be genetically similar to those from cultured flounder in Korea, and all Korean VHSV isolates were classified into the Genotype IVa group, suggesting that they originated from the same ancestor.

Marine VHSVs are represented in all 4 genotype groups and are considered to be the original reservoir of VHSVs (Einer-Jensen et al. 2004). Even though VHSV has been detected only recently in wild marine fishes in Korea, VHSV seems to have been present for a very long time in the marine environment of the Korean peninsula. Flounder are cultivated using seawater, and thus it is highly probable that marine VHSV may have been introduced to cultured flounder through the seawater used for culture. The observation that all VHSVs isolated from cultured flounder belong to Genotype IVa may be due to geography. All Korean VHSV isolates studied to date are Genotype IVa, indicating that only Genotype IVa has been introduced in cultured flounder. If other genotypes are introduced into the marine environment of the Korean peninsula, it is possible that they may be virulent to cultured flounder. Thus, it is very important to prevent the introduction of other genotypes of VHSV into cultured flounder.

The virulence factors of VHSV have not yet been determined. Like other rhabdoviruses, VHSV is highly sensitive to interferon (IFN) produced by host cells (O'Farrell et al. 2002). Thus, viral factors involved in the control of IFN levels may determine the virulence of VHSV. VHSV G has been reported to induce an IFN response (Boudinot et al. 2004, Tafalla et al. 2007) and play a decisive role in determining the virulence of VHSV (Béarzotti et al. 1995, Stone et al. 1997). The NV of IHNV, a fish rhabdovirus, has been found to suppress the host IFN response and support viral growth (Choi et al. 2011). Thus, in terms of the host IFN response, VHSV G and NV may play important roles in VHSV virulence. However, NV does not seem to be the factor responsible for the different virulence between VHSV-KR-CJA and VHSVKR-YGH; the NV sequence of VHSV-KR-CJA was identical to that of VHSV-KR-YGH (GenBank accession numbers JQ651394 and JQ651389, respectively). Comparative analysis revealed 1 nucleotide and 1 amino acid difference between the VHSV-KRCJA and VHSV-KR-YGH G genes and proteins, respectively. Consistent with our finding, there are other reports of only a single amino acid substitution in the $\mathrm{G}$ protein between high and low pathogenicity VHSV isolates (Betts \& Stone 2000, Campbell et al. 2009). In addition, in the rabies virus, another rhab dovirus, only a single point mutation within the $G$ gene was detected when comparing a virulent strain with a less virulent strain (Shimizu et al. 2007). Collectively, these suggest that a few key amino acid changes determine the virulence of rhabdoviruses. However, it is not clear how the single amino acid substitution in the $\mathrm{G}$ protein affects VHSV virulence. As the VHSV G protein is involved in the induction of the host IFN response (Boudinot et al. 2004, Tafalla et al. 2007), a substitution in the VHSV G protein might affect this induction and thus virulence. Alternatively, the change in the $G$ protein sequence may affect the efficiency of initial entry of VHSV. The rhabdovirus $G$ protein is responsible for the first steps of infection, namely attachment and fusion (Matlin et al. 1982). Recently, it was reported that the low virulence of a marine isolate of VHSV in rainbow trout was more related to defects in the initial entry and/or replication of the virus than defects in the suppression of the host IFN response (Campbell et al. 2011). Further studies of the biological roles of mutations in the G gene may reveal the role of this protein in determining the virulence of VHSV.

Here, we isolated 2 VHSV isolates, VHSV-KR-CJA and VHSV-KR-YGH, from cultured flounders during epizootics in South Korea. Field data and experimental mortality tests demonstrated that VHSV-KR-CJA is highly pathogenic while VHSV-KR-YGH is much less pathogenic to cultured flounder. Comparative sequence analysis of the genes of these 2 viruses, however, confirmed a close genetic relationship between these 2 isolates, which belong to the Genotype IVa group of VHSVs. Even though we were not able to determine the factors responsible for the different virulence of these 2 isolates, our results suggest that only small differences in the VHSV genome 
modulate the pathogenicity of VHSV. This is the first report of VHSV isolates that are genetically similar but differentially virulent in cultured flounder. The exact source of these viruses remains unknown. However, marine VHSV was likely introduced into cultured flounder as a low pathogenic VHSV strain and then evolved into a highly pathogenic strain due to a single mutation. We recommend that further VHSV introduction from marine water into fish farms be prevented to prevent VHS diseases in cultured flounder.

Acknowledgements. This study was supported by a grant from the National Fisheries Research and Development Institute (RP-2012-AQ-043).

\section{LITERATURE CITED}

Batts WN, Winton JR (1989) Enhanced detection of infectious hematopoietic necrosis virus and other fish viruses by pretreatment of cell monolayers with polyethylene glycol. J Aquat Anim Health 1:284-290

Béarzotti M, Monnier AF, Vende P, Grosclaude J, de Kinkelin P, Benmansour A (1995) The glycoprotein of viral hemorrhagic septicemia virus (VHSV): antigenicity and role in virulence. Vet Res Commun 26:413-422

> Benmansour A, Basurco B, Monnier AF, Vende P, Winton JR, de Kinkelin P (1997) Sequence variation of the glycoprotein gene identifies three distinct lineages within field isolates of viral haemorrhagic septicaemia virus, a fish rhabdovirus. J Gen Virol 78:2837-2846

> Betts AM, Stone D (2000) Nucleotide sequence analysis of the entire coding regions of virulent and avirulent strains of viral haemorrhagic septicaemia virus. Virus Genes 20: 259-262

> Boudinot P, Bernard D, Boubekeur S, Thoulouze M, Bremont M, Benmansour A (2004) The glycoprotein of a fish rhabdovirus profiles the virus-specific T-cell repertoire in rainbow trout. J Gen Virol 85:3099-3108

Campbell S, Collet B, Einer-Jensen K, Secombes CJ, Snow M (2009) Identifying potential virulence determinants in viral haemorrhagic septicaemia virus (VHSV) for rainbow trout. Dis Aquat Org 86:205-212

> Campbell S, McBeath A, Secombes C, Snow M, Collect B (2011) Interferon response following infection with genetically similar isolates of viral haemorrhagic septicaemia virus (VHSV) exhibiting contrasting virulence in rainbow trout. Fish Shellfish Immunol 30:287-294

Cha SJ, Do JW, Lee NS, An EJ, Kim YC, Kim JW, Park JW (2007) Phylogenetic analysis of betanodaviruses isolated from cultured fish in Korea. Dis Aquat Org 77:181-189

> Choi MK, Moon CH, Ko MS, Lee UH and others (2011) A nuclear localization of the infectious haematopoietic necrosis virus NV protein is necessary for optimal viral growth. PLoS ONE 6:e22362

> Dale OB, Ørpetveit I, Lyngstad TM, Kahns S, Skall HF, Olesen NJ, Dannevig BH (2009) Outbreak of viral haemorrhagic septicaemia (VHS) in seawater-farmed rainbow trout in Norway caused by VHS virus Genotype III. Dis Aquat Org 85:93-103

Dixon PF, Feist S, Kehoe E, Parry L, Stone DM, Way K (1997)
Isolation of viral haemorrhagic septicaemia virus from Atlantic herring Clupea harengus from the English Channel. Dis Aquat Org 30:81-89

> Do JW, Cha SJ, Kim JS, An EJ and others (2005) Phylogenetic analysis of the major capsid protein gene of iridovirus isolates from cultured flounders Paralichthys olivaceus in Korea. Dis Aquat Org 64:193-200

Einer-Jensen K, Olesen NJ, Lorenzen N, Jørgensen PE (1995) Use of the polymerase chain reaction (PCR) to differentiate serologically similar viral haemorrhagic septicaemia (VHS) virus isolates from Europe and America. Vet Res 26:464-469

> Einer-Jensen K, Ahrens P, Forsberg R, Lorenzen N (2004) Evolution of the fish rhabdovirus viral haemorrhagic septicaemia virus. J Gen Virol 85:1167-1179

Elsayed E, Faisal M, Thomas M, Whelan G, Batts W, Winton $\mathrm{J}$ (2006) Isolation of viral haemorrhagic septicaemia virus from muskellunge, Esox masquinongy (Mitchill), in Lake St Clair, Michigan, USA reveals a new sublineage of the North American genotype. J Fish Dis 29:611-619

Felsenstein J (1985) Confidence limits on phylogenies: an approach using the bootstrap. Evolution 39:783-791

Gagné N, Mackinnon AM, Boston L, Souter B, Cook-Versloot M, Griffiths S, Olivier G (2007) Isolation of viral haemorrhagic septicaemia virus from mummichog, stickleback, striped bass and brown trout in eastern Canada. J Fish Dis 30:213-223

> Hedrick RP, Batts WN, Yun S, Traxler GS, Kaufman J, Winton JR (2003) Host and geographic range extensions of the North American strain of viral hemorrhagic septicemia virus. Dis Aquat Org 55:211-220

Isshiki T, Nishizawa T, Kobayashi T, Nagano T, Miyazaki T (2001) An outbreak of VHSV (viral hemorrhagic septicemia virus) infection in farmed Japanese flounder Paralichthys olivaceus in Japan. Dis Aquat Org 47:87-99

Jensen MH (1965) Research on the virus of Egtved disease. Ann NY Acad Sci 126:422-426

> Kim DH, Oh HK, Eou JI, Seo HJ and others (2005) Complete nucleotide sequence of the hirame rhabdovirus, a pathogen of marine fish. Virus Res 107:1-9

Kim SM, Park SI (2004) Detection of viral hemorrhagic septicemia virus (VHSV) in wild marine fishes in the coastal region of Korea. J Fish Pathol 17:1-10

Kim SM, Lee JI, Hong MJ, Park HS, Park SI (2003) Genetic relationship of the VHSV (viral hemorrhagic septicemia virus) isolated from cultured olive flounder, Paralichthys olivaceus in Korea. J Fish Pathol 16:1-12

Kim WS, Oh MJ, Nishizawa T, Park JW, Kurath G, Yoshimizu M (2007) Genotyping of Korean isolates of infectious hematopoietic necrosis virus (IHNV) based on the glycoprotein gene. Arch Virol 152:2119-2124

> Kim WS, Kim SR, Kim D, Kim JO and others (2009) An outbreak of VHSV (viral hemorrhagic septicemia virus) infection in farmed olive flounder Paralichthys olivaceus in Korea. Aquaculture 296:165-168

Lee WL, Yun HM, Kim SR, Jung SJ, Oh MJ (2007) Detection of viral hemorrhagic septicemia virus (VHSV) from marine fish in the South Western coastal area and East China Sea. J Fish Pathol 20:201-209

López-Vázquez C, Raynard RS, Bain N, Snow M, Bandin I, Dopazo CP (2006) Genotyping of marine viral haemorrhagic septicaemia virus isolated from the Flemish Cap by nucleotide sequence analysis and restriction fragment length polymorphism patterns. Dis Aquat Org 73:23-31

> Lumsden JS, Morrison B, Yason C, Russell S and others 
(2007) Mortality event in freshwater drum Aplodinotus grunniens from Lake Ontario, Canada, associated with viral haemorrhagic septicemia virus, Type IV. Dis Aquat Org 76:99-111

Matlin KS, Reggio SH, Helenius A, Simons K (1982) Pathway of vesicular stomatitis virus entry leading to infection. J Mol Biol 156:609-631

Mortensen HF, Heuer OE, Lorenzen N, Otte L, Olesen NJ (1999) Isolation of viral haemorrhagic septicaemia virus (VHSV) from wild marine fish species in the Baltic Sea, Kattegat, Skagerrak and the North Sea. Virus Res 63: 95-106

Nishizawa $T$, Iida $H$, Takano $R$, Isshiki $T$, Nakajima $K$, Muroga K (2002) Genetic relatedness among Japanese, American and European isolates of viral hemorrhagic septicemia virus (VHSV) based on partial G and P genes. Dis Aquat Org 48:143-148

O'Farrell C, Vaghefi N, Cantonnet M, Buteau B, Boudinot P, Benmansour A (2002) Survey of transcript expression in rainbow trout leukocytes reveals a major contribution of interferon-responsive genes in the early response to a rhabdovirus infection. J Virol 76:8040-8049

Page RDM (1996) TreeView: an application to display phylogenetic trees on personal computers. Comput Appl Biosci 12:357-358

Park MA, Sohn SG, Lee SD, Chun SK, Park JW, Fryer JL, Hah YC (1993) Infectious haematopoietic necrosis virus from salmonids cultured in Korea. J Fish Dis 16:471-478

Saitou N, Nei M (1987) The neighbor-joining method: a new method for reconstructing phylogenetic trees. Mol Biol Evol 4:406-425

Schütze H, Mundt E, Mettenleiter TC (1999) Complete genomic sequence of viral haemorrhagic septicemia virus, a fish rhabdovirus. Virus Genes 19:59-65

Shimizu K, Ito N, Mita T, Yamada K, Hosokawa-Muto J, Sugiyama M, Minamoto N (2007) Involvement of nucleoprotein, phosphoprotein, and matrix protein genes of rabies virus in virulence for adult mice. Virus Res 123: 154-160

Smail DA (1999) Viral haemorrhagic septicaemia. In: Woo PTK, Bruno DW (eds) Fish diseases and disorders, Vol 3. Viral, bacterial and fungal infections. CABI Publishing, New York, NY, p 123-147

Snow M, Cunningham CO, Melvin WT, Kurath G (1999) Analysis of the nucleoprotein gene identifies distinct lineages of viral haemorrhagic septicaemia virus within the European marine environment. Virus Res 63:35-44

Editorial responsibility: Mark Crane, Geelong, Victoria, Australia
Snow M, Bain N, Black J, Taupin V, and others (2004) Genetic population structure of marine viral haemorrhagic septicaemia virus (VHSV). Dis Aquat Org 61: $11-21$

Sohn SG, Park MA, Do JW, Choi JW, Park JW (1995) Birnaviruses isolated from cultured flounder in Korea. Fish Pathol 30:279-280

Stone DM, Way K, Dixon PF (1997) Nucleotide sequence of the glycoprotein gene of viral haemorrhagic septicaemia (VHS) viruses from different geographical areas: a link between VHS in farmed fish species and viruses isolated from North Sea cod (Gadus morhua L.). J Gen Virol 78: 1319-1326

Tafalla C, Chico V, Pérez L, Coll J, Estepa A (2007) In vitro and in vivo differential expression of rainbow trout (Oncorhynchus mykiss) Mx isoforms in response to viral hemorrhagic septicemia virus (VHSV) G gene, poly I:C and VHSV. Fish Shellfish Immunol 23:210-221

Takano R, Nishizawa T, Aritmoto M, Muroga K (2000) Isolation of viral haemorrhagic septicaemia virus (VHSV) from wild Japanese flounder, Paralichthys olivaceus. Bull Eur Assoc Fish Pathol 20:186-192

Takano R, Mori K, Nishizawa T, Arimoto M, Muroga K (2001) Isolation of viruses from wild Japanese flounder Paralichthys olivaceus. Fish Pathol 36:153-160

Thompson JD, Higgins DG, Gibson TJ (1994) CLUSTAL W: improving the sensitivity of progressive multiple sequence alignment through sequence weighting, position-specific gap penalties and weight matrix choice. Nucleic Acids Res 22:4673-4680

Thiéry R, de Boisséson C, Jeffroy J, Castric J, de Kinkelin P, Benmansour A (2002) Phylogenetic analysis of viral haemorrhagic septicaemia virus (VHSV) isolates from France (1971-1999). Dis Aquat Org 52:29-37

Walker PJ, Benmansour A, Calisher CH, Dietzgen R, and others (2000) Family Rhabdoviridae. In: van Regenmortel MHV, Fauquet CM, Bishop DHL, Carstens EB and others (eds) The seventh report of the international committee for taxonomy of viruses. Academic Press, San Diego, CA, p 563-583

Winton J, Batts WN, Nishizawa T (1989) Characterization of the first North American isolates of viral hemorrhagic septicaemia virus. Am Fish Soc Fish Health Section Newsl 17:2-3

Wolf K (1988) Viral hemorrhagic septicemia. In: Wolf K (ed) Fish viruses and fish viral diseases. Cornell University Press, Ithaca, NY, p 217-249

Submitted: May 7, 2012; Accepted: July 10, 2012 Proofs received from author(s): October 25, 2012 